\title{
Den danske religionsmodels grænseflade
}

\author{
MARGIT WARBURG
}

\begin{abstract}
ENGLISH ABSTRACT: The Danish model of religion designates the conditional ways according to which the Danish national church and other parts of the system of religion are unfolded in Danish society. The special constitutional position of the national church and its dominance in terms of demography of religion explains why the national church constitutes the core of the Danish model of religion. Between this churchly core and the surrounding society the Danish model of religion has a mediate space, which harbours a number of groups and actors who are part of the model of religion, though without a central position in it. The article discusses the historical development of the Danish model of religion and its characteristics. Additionally, it provides some examples of groups and institutions that are placed at the fringes of the model.
\end{abstract}

DANSK RESUMÉ: Ved den danske religionsmodel forstås de former og rammer, hoorunder folkekirken og de øvrige dele af religionssystemet udfoldes $i$ det danske samfund. Folkekirkens grundlovssikrede særstilling og dens religionsdemografiske dominans er grunden til, at folkekirken udgør kernen i den danske religionsmodel. Mellem denne folkekirkelige kerne og det omgivende samfund har den danske religionsmodel en grænseflade, som rummer en række grupper og aktører, der indgår i religionsmodellen, dog uden at være centralt placeret her. Artiklen behandler den danske religionsmodels historiske udvikling og karakteristika og omtaler nogle eksempler på grupper og institutioner, som er placeret i religionsmodellens grænseflade.

KEYWORDS: Model of religion; functional differentiation; Denmark; state and church; constitution

Med kong Harald Blåtand (958-986) indledtes et mere end tusindårigt forhold mellem stat og kirke i Danmark. Den store Jellingsten, som Harald lod rejse for blandt 
andet at bryste sig af, at han 'gjorde danerne kristne', er Danmarks officielle symbol på indledningen til dette forhold.

De to Jellingsten er som bekendt i de seneste årtier blevet så forvitrede, at staten, repræsenteret ved Kulturstyrelsen, måtte gribe ind i 2011 og beskytte dem med klimastyrede glashuse. Forvitringsprocessen kan ses som et symbol på en begyndende opblødning af det hidtil så faste forhold mellem kirke og stat i Danmark. Denne opblødning blev officielt markeret ved, at kirkeminister Manu Sareen i september 2012 nedsatte et udvalg, som skulle komme med forslag til en fremtidig styringsstruktur for folkekirken. Som led i dette arbejde udarbejdede udvalget et offentligt debatoplæg (Debatoplæg 2013), og på baggrund af diskussionen af oplægget afsluttede udvalget sit arbejde i april 2014 med en betænkning, Folkekirkens styre (Betænkning 1544 2014). Som Marie Vejrup Nielsen skriver i dette temanummer, synes dog allerede debatoplægget at udstikke grænser for, hvor vidtgående sådanne ændringer kan være for at kunne rummes inden for begrebet folkekirke.

Udsendelsen af Betænkning 1544 skabte forventninger om, at grundlovens såkaldte løfteparagraf, "Folkekirkens forfatning ordnes ved lov" (§66), ville blive indfriet efter mere end 165 år. Den 30. oktober 2014 meddelte Venstre og Det Konservative Folkeparti imidlertid, at de ikke ville medvirke til ny lovgivning om folkekirkens styre, og dermed bortfaldt muligheden for et bredt politisk forlig i nær fremtid om centrale ændringer i den danske religionsmodel (Jelved 2014). Udviklingen falder helt i tråd med, at danske politikere traditionelt har været tilbageholdende over for forandringer på det religionspolitiske område (Christensen 2012). Det er i modsætning til de øvrige nordiske lande, som i de seneste årtier har gennemført betydelige politiske og organisatoriske ændringer i forholdet mellem stat og kirke og i statens forhold til andre trossamfund (Nielsen 2012). De mest vidtgående ændringer skete i Sverige med en formel adskillelse af stat og kirke i 2000.

Den politiske debat om stat og kirke i Norden har ofte taget udgangspunkt i den demografiske og religiøse udvikling i de nordiske lande. Siden 1970'erne har medlemskabet af de dominerende evangelisk-lutherske kirker været langsomt, men støt faldende, samtidig med, at der er et stigende antal borgere, som har tilknytning til andre trossamfund, først og fremmest de muslimske. I det øvrige Europa ses den samme tendens mod en religionspolitisk opmærksomhed på statens forhold ikke bare til de dominerende kirker, men også til andre trossamfund og til bredere spørgsmål om individers og religiøse gruppers rettigheder og pligter $\mathrm{i}$ forhold til statsmagten (Christoffersen 2012a).

Forskningsnetværket Den danske religionsmodel under forandring: Et komparativt perspektiv er støttet af Det Frie Forskningsråd I Kultur og Kommunikation, og netværket har til formål at belyse den danske religionsmodel i dens konkrete historiske og aktuelle udformning og sætte den ind i et komparativt europæisk perspektiv. ${ }^{1}$ Dette temanummer af Religionsvidenskabeligt Tidsskrift indeholder en række forskningsbi-

1 Se netværkets hjemmeside http://dendanskereligionsmodel.ku.dk/ 
drag, som specielt retter sig mod det, vi har kaldt den danske religionsmodels grænseflade, og som vil blive uddybet teoretisk i det følgende.

\section{Hvad er en religionsmodel?}

Vores arbejde i netværket med den danske religionsmodel har som det teoretiske udgangspunkt funktionel differentiering med vægt på en historisk orienteret forståelse af Niklas Luhmanns sociologi (Ziemann 2007). En kort fremstilling af denne forståelse er, at den historiske udvikling i de vesteuropæiske samfund har medført en opdeling af samfundet i delvist autonome systemer, som i høj grad er selvrefererende samtidig med, at de også interagerer. Udviklingen af disse forskellige, selvrefererende og gensidigt interagerende samfundssystemer og deres indbyrdes dynamik er kernen i en historisk-sociologisk forståelse af funktionel differentiering.

Religionssystemet indtager en central position som et af de ældste og vigtigste af disse samfundssystemer. Middelalderens katolske kirke i Europa havde en betydelig økonomisk og militær magt på statsniveau. Samtidig kunne den påberåbe sig en religiøs autoritet, som var legitimeringsgrundlaget for den herskende samfundsorden, og som gav den styrke til at anvise en moralsk rettesnor for den enkeltes levevis, tro og adfærd. Derudover beskæftigede kirken sig, især gennem klostrene, med produktion, sundhed, socialvæsen og uddannelse.

I højmiddelalderen blev sporene lagt for en uddifferentieringsproces, som med grundlæggelsen af de første universiteter i 1100- og 1200-tallet langsomt gjorde højere uddannelse til et selvstændigt system i forhold til kirken. Senere fulgte sundhedsvæsen og socialvæsen, og lige som universiteterne er disse systemer også i dag stadig præget af deres historiske baggrund i kirken (Kahl 2009).

Med reformationen blev den dansk-norske konge og flere andre europæiske fyrster overhoved for hver deres del af religionssystemet, og den augsburgske fred i 1555 cementerede de protestantiske fyrstekirkers religiøse monopol. De indbyggere i det danske kongerige, som ikke tilhørte den lutherske tro, var således ikke almindelige undersåtter. De opholdt sig i landet på særlige vilkår, det gjaldt for eksempel jøderne og de reformerte i fristæderne Fredericia og Altona. Især efter enevældens indførelse i 1660 blev forbindelserne mellem den danske stat og kirken meget tætte. Biskopperne mistede deres indflydelse på rigets politiske anliggender, de blev nu ansat og afskediget af kongen, og med indførelsen af et fælles dansk-norsk kirkeritual i 1685 var kirken reelt blevet underlagt staten. Man kan her tale om, at forholdet mellem kirke og stat undergik en de-differentiering (Gorski 2000). Funktionel differentiering er i det hele taget ikke en historisk lineær proces, som leder til en stadig opsplitning i nye subsystemer; der er også tale om, at de enkelte systemer kan ændres ved uddifferentiering af gamle opgaver og indfusionering af nye.

Med indførelsen af grundloven i Danmark i 1849 blev kirkens religiøse monopolstilling ophævet, statskirken blev omdannet til en ministerielt rammestyret folkekir- 
ke med tiltagende ansvar for egne anliggender, og grunden blev i store træk lagt til den danske religionsmodel, som den så ud indtil 1970'erne. Sundheds- og socialvæsenet var ikke længere en del af religionssystemet, og det samme gjaldt uddannelse ud over folkeskoleniveau. Grundskolen blev noget langsommere uddifferentieret fra religionssystemet og er det ikke helt endnu (Reeh 2012). Samtidig betød den grundlovssikrede religionsfrihed, at en række religiøse mindretalssamfund gradvist blev indfusioneret i religionssystemet med nogle civilretlige rettigheder, der ligner folkekirkens, som for eksempel vielsesbemyndigelse (Warburg 1998).

Begrebet den danske religionsmodel blev introduceret i bogen Fremtidens danske religionsmodel, redigeret af Lisbet Christoffersen, Hans Raun Iversen, Niels Kærgård og Margit Warburg. Bogen udkom i efteråret 2012, og den gav dermed en faglig optakt til aktiviteterne i forskningsnetværket, som har de fire redaktører i styregruppen. I indledningskapitlet definerede vi begrebet religionsmodel og karakteriserede den danske religionsmodel således:

Med udtrykket den danske religionsmodel forstår vi de former og rammer, hvorunder religionssystemet udfoldes i det danske samfund. Religionsmodellen er det institutionaliserede og historisk betingede aftryk, som religionssystemets udvikling og interaktion med staten og samfundet gennem historien har efterladt os med. Den danske religionsmodel består derfor af en række træk af historisk, sociologisk, mentalitetsmæssig, juridisk, økonomisk, politisk, teologisk etc. art, som er relativt særegne for det danske samfund (Christoffersen et al. 2012, 14; kursiveringen er fra bogen).

Grundtrækkene i en stats religionsmodel er som regel beskrevet i forfatningen og andre centrale retsakter. Et kendt eksempel fra udlandet er USA's First Amendment (til den amerikanske forfatning), som fastslår religionsfriheden og samtidig forbyder, at en bestemt religion kan få en statslig fortrinsret. Et andet eksempel er Italien, hvor forholdet mellem den italienske stat og den katolske kirke er reguleret gennem Lateran-overenskomsterne fra 1929, også kaldet konkordatet. Heri accepterede paven Italiens erobring i 1870 af de pavelige besiddelser i Mellemitalien og anerkendte den italienske stat mod til gengæld at få anerkendt Vatikanstaten som en suveræn stat og få en fortrinsstilling for den katolske kirke i Italien. Konkordatet er blevet revideret et par gange siden, men det var først i 1984, at det blev bestemt, at den katolske kirke ikke længere skulle være den italienske stats officielle religion.

\section{Den danske religionsmodel}

I Danmark hviler religionsmodellen på flere paragraffer i grundloven samt en række andre love og bestemmelser af civilretlig karakter. Religionsfriheden er grundlovssikret gennem $\S 67$, som giver borgerne ret til frit at forsamle sig med gudsdyrkelse som formål samt $\$ 70$, som sikrer borgernes retslige ligestilling uanset deres religion. Folkekirkens særstatus fremgår af grundlovens §4, som fastslår, at “den evangelisk- 
lutherske kirke er den danske folkekirke og understøttes som sådan af staten". Denne paragraf samt $\S 6$, som gør det pligtigt for monarken at tilhøre den evangelisklutherske kirke, placerer folkekirken helt centralt i den danske religionsmodel.

I artiklen "Religion as a cultural system" skelner Clifford Geertz mellem to typer modeller, a model of og a model for (Geertz 1993, 93). Den første type er en afspejling af virkeligheden, den anden type er udgangspunkt for at forme virkeligheden. I studierne af den danske religionsmodel er det vores analytiske tilgang at se på den danske religionsmodel som en deskriptiv, historisk størrelse, dvs. som en model af en virkelighed, som er mangfoldig og ind imellem modsætningsfyldt for ikke at sige både livfuld og rodet - nærmest som et teenageværelse! Den danske folkekirkeordning synes for eksempel at være blevet til gennem en afbalancering af så mange modstridende hensyn, at det er næsten uladsiggørligt selv i dag at forene disse hensyn ved en eventuel nyordning af folkekirkens styring (Christensen 2012; Holm 2012).

Man skal dog ikke være blind for den forskningsmæssige betydning af, at den danske religionsmodel på vigtige punkter også er en model for, hvordan organiseret religion skal håndteres af den danske stat. For eksempel foreskriver de administrative retningslinjer for godkendelse af trossamfund uden for folkekirken, at de skal være organiseret efter dansk foreningspraksis, og at der skal foreligge tilgængelige beskrivelser af trosgrundlag og de væsentligste ritualer. Det sidste kan få konsekvenser for en eventuel godkendelse af trossamfund med esoteriske traditioner og ritualer. ${ }^{2}$ Desuden skal trossamfundet efterleve menneskerettighederne. Her stiller den danske stat altså nogle normative betingelser for, hvordan et trossamfund skal indrette sig, for at det kan opnå det privilegium at blive godkendt (Vinding 2012).

Som påpeget af Lisbet Christoffersen i Fremtidens danske religionsmodel hviler folkekirkens grundlovssikrede særstilling på et underforstået kriterium om, at befolkningens flertal skal være medlemmer (Christoffersen 2012b). Det er flertallet da også stadigvæk, selv om de seneste årtiers religiøse forandringer i Danmark er betydelige. Så sent som i 1974 var 95,2 pct. af danskerne medlem af folkekirken (Danmarks Statistik 1977). Ved årsskiftet 2011/2012 udgjorde folkekirkens medlemstal for første gang mindre end 80 pct. af befolkningen, og pr. 1. april 2014 var 78,3 pct. af danskerne medlem af folkekirken. ${ }^{3}$

De øvrige trossamfund i Danmark har kvantitativt set stadig kun en beskeden placering i det religiøse landskab. I runde tal har udviklingen i danskernes religiøse tilhørsforhold fra 1974 og til i dag været som vist i tabel 1.

2 Dette er begrundet i, at offentligheden skal have sikkerhed for, at trossamfundet efterlever grundlovens $\S 67$, som stiller krav om, at der i trossamfundet "intet læres eller foretages, som strider mod sædeligheden eller den offentlige orden". Dertil kommer, at alle medlemmerne skal have adgang til religionens lære, blandt andet fordi der forudsættes en fælles tro, for at der foreligger et trossamfund. Se vejledende retningslinjer udarbejdet af Det Rådgivende Udvalg vedr. Trossamfund 6. rev. udgave, den 18. august 2011, http://www.familiestyrelsen.dk/fileadmin/ user_upload/Trossamfund/Vejledende-retningslinjertrossamfund.pdf (set 4.9.2014).

3 Antallet af medlemmer pr. 1. april 2014 var 4.409 .203 og befolkningstallet var 5.634.437, se http://www.dst.dk/da/Statistik/emner/folkekirken/medlemmer-af-folkekirken.aspx (set 4.9.2014). 
Tabel 1. Udviklingen i danskernes religiøse tilhørsforhold

\begin{tabular}{lccccc}
\hline & & $\begin{array}{l}\text { Øvrige } \\
\text { kristne } \\
\text { grupper }\end{array}$ & $\begin{array}{l}\text { Ikke- } \\
\text { kristne } \\
\text { grupper }\end{array}$ & $\begin{array}{l}\text { Uden religiøst } \\
\text { tilhørsforhold }\end{array}$ & I alt \\
\hline 1974 & 95 pct. & 2 pct. & 1 pct. & 2 pct. & 100 pct. \\
2014 & 78 pct. & 2 pct. & 5 pct. & 15 pct. & 100 pct. \\
\hline
\end{tabular}

Tallet for folkekirken 2014 er fra Statistikbanken, Danmarks Statistik, de øvrige tal er baseret på vurderinger fra mange forskellige kilder. Tilhørsforholdet til de ikke-kristne grupper er blandt andet vurderet ud fra data om indvandreres formodede religiøse baggrund $i$ deres oprindelsesland (se for eksempel Jacobsen 2007). Da det imidlertid er kendt, at hovedparten af de danske muslimer ikke er medlemmer af noget muslimsk trossamfund, så vil de angivne tal overvurdere medlemstallet. Det er også under halvdelen af de ca. 6000 danske jøder, som er medlemmer af Det Jødiske Samfund i Danmark (Mosaisk Troessamfund).

Det langsomme men støtte fald i folkekirkens medlemstal skyldes således kun i mindre udstrækning, at andre trossamfund er vokset; hovedparten af faldet skyldes udmeldelser og ikke mindst et fald i dåbsprocenten. I 1990 var dåbsprocenten på landsplan 80,6 pct. af alle étårige børn i Danmark, men i 2010 var denne andel faldet til 69,2 pct., hvor Københavns Stift var i bund med en dåbsprocent på blot 46,3 pct. (Fusager 2012). En simpel demografisk fremskrivning indikerer imidlertid, at selv om dåbsprocenten nogle steder i landet er under 50 pct., så vil det vare årtier, inden folkekirken tæller mindre end halvdelen af danskerne som medlemmer. En sådan fremskrivning er i øvrigt behæftet med så usikre forudsætninger, at den ikke har megen lødighed.

Overordnet bekræfter tabel 1, at folkekirken er det helt dominerende trossamfund i Danmark, og dens centrale placering i den danske religionsmodel antastes i hvert fald ikke af andre trossamfund.

\section{Hvad karakteriserer religionsmodellens grænseflade?}

I forskningsnetværket Den danske religionsmodel under forandring har vi både analyseret religionsmodellens folkekirkelige kerne og dens ydre samspil med det øvrige samfund. Påvirkningen fra lutherdommen er fortsat meget synlig i den danske samfundsmodel. Centrale eksempler herpå er, at religion og politik tilstræbes holdt adskilt, at der er stor tilslutning til ideen om en universel velfærdsstat, og at danskerne gennemgående har en protestantisk arbejdsmoral og et egalitært menneskesyn (Mannow \& Kersbergen 2009). Det er imidlertid et åbent spørgsmål, om folkekirken stadig har betydning for disse forhold, eller om uddifferentieringen er nået så langt, 
at disse træk ved den danske samfundsmodel har en selvopretholdende, egen dynamik (Kaspersen \& Lindvall 2008).

Mellem den folkekirkelige kerne og samfundet uden for folkekirken har den danske religionsmodel en grænseflade, hvor folkekirkelige traditioner og aktører interagerer med det øvrige samfund. Disse interaktioner er i høj grad båret af lutherdommens historiske indflydelse på samfundsinstitutioner og mentalitet i Danmark. Desuden rummer religionsmodellens grænseflade andre grupper og aktører, som ikke kan placeres centralt i modellen, men som på den anden side heller ikke med rimelighed kan placeres helt udenfor.

Først og fremmest er der selvfølgelig de andre trossamfund, der som nævnt langsomt er blevet indfusioneret i den danske religionsmodel. Fra 1970 ophørte praksis med at anerkende trossamfund ved kongelig resolution, og i stedet sker der en administrativ godkendelse efter ansøgning. Den ministerielle godkendelse sker i dag på basis af en konkret vurdering fra et ekspertudvalg efter en række kriterier og retningslinjer, se ovenfor. Pr. 24. juli 2014 var der 158 trossamfund, der havde opnået godkendelse, inklusive dem, der blev anerkendt ved kongelig resolution allerede under enevælden. ${ }^{4}$

Man kan muligvis synes, at det er 'noget pinagtigt', at grundlovens $§ 69$ omtaler de andre trossamfund som "de fra folkekirken afvigende trossamfund" (Christoffersen 2012b), men deres afvigerstatus i religionsmodellen er en sociologisk kendsgerning. Trossamfundene har en deriveret status i forhold til folkekirken, hvad enten de ønsker det eller ej. Det er derfor, vi har valgt at placere de øvrige trossamfund i Danmark i den danske religionsmodels grænseflade. Det gælder også et ikketrossamfund, som Dansk Humanistisk Samfund, hvor medlemmerne muligvis gerne ville have sig frabedt at blive placeret i den danske religionsmodel, selv om det dog er i dens grænseflade! Dansk Humanistisk Samfund indgår i religionsmodellens grænseflade, fordi det i sit idegrundlag og sine ceremonier er et spejlbillede af et trossamfund, som Niels Reeh også påpeger i dette temanummer.

Der er også organisationer og institutioner, som har en vis tilknytning til folkekirken, men alligevel har en særstatus. Det gælder de 30 danske menigheder i Sydslesvig og de knap 40 danske menigheder i det øvrige udland. På nogle måder er disse udlandsmenigheder en del af folkekirken og på andre måder ikke, og de artikulerer nogle væsentlige problemstillinger for den danske religionsmodel (Warburg 2012a; Warburg 2012b). Margit Warburg diskuterer i dette temanummer, hvordan den religionsdemografiske udvikling i udlandskirkerne påvirker deres placering i den danske religionsmodels grænseflade.

Debatten om kirkelukninger i København har blandt andet rejst spørgsmålet om, hvem der ejer kirkebygningerne og har dispositionsretten over dem (Larsen 2013). Hans Raun Iversen diskuterer dette spørgsmål med udgangspunkt i de planlagte

4 http://sm.dk/arbejdsomrader/trossamfund/anerkendte-og-godkendte-trossamfund-og-menigheder/alle (set 24.8.2014) 
kirkelukninger i Københavns Stift i 2013. Menighedsrådet i et sogn har ganske vist ansvaret for kirkebygningens vedligeholdelse, men dispositionsretten er indskrænket af overordnede folkekirkelige hensyn og i de fleste tilfælde også af kulturhistoriske hensyn (Kirker og kirkegårde 2001). Jo mere tungtvejende disse kulturhistoriske, verdslige hensyn bliver, desto længere ude ligger den pågældende kirkebygning i religionsmodellens grænseflade, væk fra dens kerne. Det er en problemstilling, som helt konkret manifesterer sig for Roskilde Domkirkes vedkommende, som diskuteret af Lisbet Christoffersen i dette temanummer.

Kirkebygninger og andre religiøse bygninger er ofte markante arkitektoniske indslag i bybilledet, og de vender dermed i høj grad ud mod det omgivende samfund. Som anført af Brian Arly Jacobsen i dette temanummer, så taler det for at se på religiøse bygninger som en del af religionsmodellens grænseflade. I det hele taget er spørgsmålet om synligheden af religion i det offentlige rum relevant for diskussionen om afgrænsningen af den danske religionsmodel fra det øvrige samfund. I sin artikel i dette temanummer angriber Peter Lüchau dette spørgsmål ud fra en kvantitativ sociologisk undersøgelse af, hvad danskernes syn er på "religionens rette plads" i Danmark.

Placeringen i grænsefladen er dynamisk, og den kan ændres over tid. Nogle grupper og institutioner i grænsefladen bevæger sig udad, mens andre bevæger sig indad, og der er eksempler på begge dele i de forskellige bidrag til temanummeret. Som påpeget af Margit Warburg er nogle af de danske udlandskirker på vej ud af religionsmodellen. Omvendt er der religiøse minoritetsgrupper, som bevæger sig indad. Annika Hvithamar viser, at det gælder for Jehovas Vidner, som gradvist har accepteret mere og mere af den danske samfundsmodel, herunder at være et godkendt trossamfund og dermed deres placering i den danske religionsmodel. Astrid Krabbe Trolle behandler i sin artikel et andet eksempel, nemlig at staten og folkekirken er ved at åbne op for, at nogle nyere protestantiske migrantkirker kan blive en del af folkekirken via valgmenighedsloven. Dermed bevæger disse migrantkirker sig fra religionsmodellens grænseflade hen mod modellens kerne.

Den danske religionsmodels grænseflade markerer således ikke nogen skarp grænse mellem det omgivende samfund og religionsmodellens kerne, nemlig den danske folkekirke. Grænsefladen er - som når vi normalt taler om grænseflader i humaniora og samfundsvidenskaberne - diffus. Det er derfor naturligt at stille spørgsmålet: Hvor er det videnskabeligt meningsfyldt at tale om grænsefladen, og hvor er det - bogstaveligt talt - for langt ude at tale om en grænseflade? Det kan vi efter min opfattelse bedst danne os et indtryk af ved at undersøge og diskutere forskellige konkrete eksempler, som vi i udgangspunktet antager hører med til grænsefladen. Dette temanummer giver netop nogle forskellige eksempler, som kan danne grundlag for en sådan diskussion. Eksemplerne sættes til slut i et skandinavisk komparativt perspektiv gennem Ulla Schmidts og Jørgen Straarups artikler om religionsmodellerne og deres grænseflader i henholdsvis Norge og Sverige. 
Jeg vil afslutte med at sige tak til Pernille Friis Jensen, Camilla Søgaard Kristensen, Bjarke Schønwandt Mortensen og Mie Marie Hjartdal Morthorst, som Astrid Krabbe Trolle og jeg har diskuteret de enkelte kapitler med. De fire studerende har med dygtighed og fagligt engagement bidraget til det redaktionelle arbejde med dette temanummer.

\section{LITTERATURLISTE}

Betænkning 1544

2014 Folkekirkens styre. Betænkning fra Udvalget om en mere sammenhængende og moderne styringsstruktur for folkekirken, Kirkeministeriet, april 2014, København.

Christensen, Liselotte J.

2012 "Ideologier bag den politiske håndtering af religionsforholdene i Danmark 1849-1922", in: Lisbet Christoffersen, Hans Raun Iversen, Niels Kærgård \& Margit Warburg, eds., Fremtidens danske religionsmodel, Anis, København, 199-215.

Christoffersen, Lisbet

2012a "Religion, politik og ret i Europa", in: Lisbet Christoffersen, Hans Raun Iversen, Niels Kærgård \& Margit Warburg, eds., Fremtidens danske religionsmodel, Anis, København, 71-101.

2012b "Den aktuelle danske religionsretlige model", in: Lisbet Christoffersen, Hans Raun Iversen, Niels Kærgård \& Margit Warburg, eds., Fremtidens danske religionsmodel, Anis, København, 239-258.

Christoffersen, Lisbet, Hans Raun Iversen, Niels Kærgård \& Margit Warburg

2012 "Den danske religionsmodel”, in: Lisbet Christoffersen, Hans Raun Iversen, Niels Kærgård \& Margit Warburg, eds., Fremtidens danske religionsmodel, Anis, København, 13-20.

Danmarks Statistik

1977 "Kirkestatistik 1974", Statistiske Efterretninger 69 (4): 97-111.

Debatoplæg

2013 Debatoplæg fra Udvalget om en mere sammenhængende og moderne styringsstruktur for folkekirken, Kirkeministeriet, april 2013, København.

Fusager, Sille M.

2012 Demografisk Analyse - med kirkeligt perspektiv af Danmark 2012, Kirkefondet, Frederiksberg.

Geertz, Clifford

1993 "Religion as a cultural system", in idem, The Interpretation of Cultures. Selected Essays, Fontana Press, Waukegan (IL), 87-125.

Gorski, Philip S.

2000 "Historicizing the Secularization Debate: Church, State, and Society in Late Medieval and Modern Europe, ca. 1300 to 1700", American Sociological Review 65, 138-167.

Holm, Anders

2012 "Mellem frihed og orden. Den danske religionsmodel kirkehistorisk betragtet", in: Lisbet Christoffersen, Hans Raun Iversen, Niels Kærgård \& Margit Warburg, eds., Fremtidens danske religionsmodel, Anis, København, 171-182.

Jacobsen, Brian

2007 "Muslimer i Danmark - en kritisk vurdering af antalsopgørelser", in: Margit Warburg \& Brian Jacobsen, eds. Tørre tal om troen. Religionsdemografi i Danmark $i$ det 21.århundrede, Forlaget Univers, Højbjerg, 143-165.

Jelved, Marianne

2014 "Ingen aftale om folkekirkens styre", Pressemeddelelse 31. oktober 2014, Kirkeministeriet, København. 
Kahl, Sigrun

2009 "Religion as a Cultural Force: Social Doctrines and Poor Relief Traditions", in: Kees van Kersbergen \& Philip Manow, eds., Religion, Class Coalitions and Welfare State Regimes, Cambridge University Press, Cambridge, 267-295

Kaspersen, Lars Bo \& Johannes Lindvall

2008 "Why No Religious Politics? The Secularization of Poor Relief and Primary Education in Denmark and Sweden", Archives Européennes de Sociologie 49, 119-143.

Kirker og kirkegårde

2001 Kirkeministeriet, 2. udg., København.

Larsen, Knud E.

2013 "Hvem ejer egentlig de danske kirker?", Kristeligt Dagblad, 19. september.

Manow, Philip \& Kees van Kersbergen

2009 "Religion and the Western Welfare State - The Theoretical Context", in: Kees van Kersbergen \& Philip Manow, eds., Religion, Class Coalitions and Welfare State Regimes, Cambridge University Press, Cambridge, 4-37.

Nielsen, Marie Vejrup

2012 "Kirkelig autonomi i de nordiske lande - perspektiver på den danske situation", in: Lisbet Christoffersen, Hans Raun Iversen, Niels Kærgård \& Margit Warburg, eds., Fremtidens danske religionsmodel, Anis, København, 41-54.

Reeh, Niels

2012 “Statens interesser i religionsundervisning fra enevælden til New Public Management", in: Lisbet Christoffersen, Hans Raun Iversen, Niels Kærgård \& Margit Warburg, eds., Fremtidens danske religionsmodel, Anis, København, 151-169.

Vinding, Niels Valdemar

2012 "De fra folkekirken afvigende trossamfund" - mellem flertalsdominans og mindretalstilpasning i den danske religionsmodel", in: Lisbet Christoffersen, Hans Raun Iversen, Niels Kærgård \& Margit Warburg, eds., Fremtidens danske religionsmodel, Anis, København, 291-305.

Warburg, Margit

1998 "Restrictions and Privileges - The Legal and Administrative Practice Towards Minority Religions in the USA and Denmark", in: Eileen Barker \& Margit Warburg, eds., New Religions and New Religiosity, Aarhus University Press, Århus, 262-275.

Warburg, Margit

2012a "Når det hellige og det verdslige rum smelter sammen. Danske kirker i udlandet og en dansk offentlig sfære", Religionsvidenskabeligt Tidsskrift 58, 21-32.

Warburg, Margit

2012b "Den danske religionsmodel i den store vide verden", in: Lisbet Christoffersen, Hans Raun Iversen, Niels Kærgård \& Margit Warburg, eds., Fremtidens danske religionsmodel, Anis, København, 55-70.

Ziemann, Benjamin

2007 "The Theory of Functional Differentiation and the History of Modern Society. Reflections on the Reception of Systems Theory in Recent Historiography", Soziale Systeme 13, 220-229.

Margit Warburg, professor, dr. phil. Institut for Tværkulturelle og Regionale Studier, Københavns Universitet 